\title{
Percy Hall Grimshaw, I.S.O., F.R.E.S.
}

Percy Hall Grimshaw was born in Leeds in 1869 , and after a conventional education there entered the service of one of the city's banks. His interests, however, were in natural history, so that when opportunity offered in I 895 he followed a fellow-townsman, Dr Eagle Clarke, to the Edinburgh Museum of Science and Art. There, under its newer name of The Royal Scottish Museum, he occupied increasingly important posts in the Natural History Department, until when he retired in 1935 he had been its Keeper for five years.

Although Grimshaw's earlier interests had been botanical, the needs of the Museum demanded that he should turn to the lower animals, and particularly Insects. He took up the study with zest, and one result became evident in the galleries, where for the first time typical collections of Insects, British and foreign, neatly arranged and properly labelled, made their appearance. He entered the Museum service under a regime which regarded exhibits as devised for the serious student and looked upon the inquisitive public as a body to which no special encouragement should be held out. Latin names demarked the specimens; English names, even of British birds, were frowned upon as "unscientific." He lived through a period when the general cultural value of museum collections has been increasingly recognised, and as a consequence he saw many changes in the aim and methods of museum display. It is evidence of his movement with the times that one of the developments of his keepership was the creation of a "Children's Gallery" in which natural history truths are suggested by simple series of exhibits.

As well as revising and regenerating both the exhibited and cabinet collections of Insects, Grimshaw made many contributions to our knowledge of the class. He contributed to the Transactions of this Society in I 898 an account of certain type-specimens of Lepidoptera and Coleoptera in the famous collection of Du Fresne of Paris, which had been purchased by the University of Edinburgh in I8I9 for $£ 3000$ and had with much heartburning been handed over to the Government at the foundation of its Museum some forty years later. But his investigations mostly related to the Diptera and their distribution in Scotland, and in pursuit of that study he made many collecting trips to parts of the mainland and to the outer islands. The result has been a great addition to the knowledge of the 
Dipterous fauna of this country, mainly contained in the pages of The Annals of Scottish Natural History and its successor The Scottish Naturalist, with the editing of which he was for long closely associated.

He shared in the production of Bartholomew's great Atlas of Zoogeography, and the records he collected for that outstanding work were, like all his accomplishment, characterised by close attention to detail and minute accuracy. His services were publicly recognised when, in I933, the Imperial Service Order was bestowed upon him.

Still full of vigour, he died suddenly in Edinburgh on November 14, 1939, at the age of sixty-nine years.

He was elected a Fellow in I9 Io.

J. R. 